\title{
A argumentação como ferramenta de reflexão e negociação para a construção de um projeto pedagógico interdisciplinar ${ }^{1}$
}

\author{
Argumentation as a tool to reflect and negotiate the construction of an \\ interdisciplinary project
}

\author{
Maísa Helena Brum ${ }^{* *}$ \\ Luciane Kirchhof Ticks***
}

\begin{abstract}
RESUMO: A prática argumentativa não é tão somente a expressão de uma avaliação individual, mas se constitui como uma contribuição para o processo comunicativo entre pessoas ou grupos, que trocam ideias com o propósito de deliberar sobre as suas diferenças de opinião (VAN EEMEREN; GOOTENDORST, 2009, p. 55). Nesse processo, destacamos a natureza dual de negociação e mudança da argumentação, que a constitui como um recurso epistêmico de mediação na construção do conheci-mento (LEITÃO, 1999). Considerando essa perspectiva, este trabalho tem como objetivo analisar o processo argumentativo desencadeado em um programa de formação continuada de professores com vistas à discussão do conceito de interdisciplinaridade e à produção de atividades pedagógicas ABSTRACT: The argumentative practice is not only the expression of a personal evaluation, but it is constituted as a contribution to the communicative process established among people or groups which exchange ideas with the purpose of deliberating about their differences of opinion (VAN EEMEREN; GOOTEN-DORST, 2009, p. 55). In this process, we highlight the dual nature of negotiation and change of argumentation, which constitutes it as an epistemic resource of mediation in the construction of knowledge (LEITÃO, 1999). Considering this perspective, the objective of this paper is to analyze the argumentative process developed in a continuing teacher education program, with the purpose of discussing the concept of interdiscipli-narity and the production of interdisci-plinary pedagogical activities, with teachers of an interdisciplinares, desenvolvido com elementary and Young and Adult
\end{abstract}

\footnotetext{
${ }^{1}$ Este trabalho faz parte da dissertação de mestrado da primeira autora citada.

${ }^{* *}$ Doutoranda em Letras pela Universidade Federal de Santa Maria/RS e professora do Instituto Federal do Rio Grande do Sul - Campus Sertão. ORCID 0000-0002-6154-8964. maisahbrum@gmail.com

*** Doutora em Letras pela Universidade Federal de Santa Maria/RS e professora do curso de graduação em Letras/Inglês e do Programa de Pós-Graduação em Letras da Universidade Federal de Santa Maria/RS. 1kirchhofticks@gmail.com
} 


\begin{tabular}{|c|c|}
\hline $\begin{array}{l}\text { Adultos (EJA) de Santa Maria } \\
\text { tanto, adotamos os pl } \\
\text { Interdisciplinaridade propos } \\
\text { Lenoir (2008). O corpus é const } \\
\text { transcrições de três sessões }\end{array}$ & $\begin{array}{l}\text { Education public school of Santa Maria, } \\
\text { RS. The corpus is constituted by } \\
\text { transcriptions of three (3) reflective } \\
\text { sessions developed in 2012, which were } \\
\text { the most representative in the reflective } \\
\text { process developed as part of a master's } \\
\text { degree investigation. The analysis of the } \\
\text { sections evidenced the presence of a } \\
\text { sequence of discursive actions. These } \\
\text { actions drove the participants' } \\
\text { negotiations in the constitution of an } \\
\text { interdisciplinary pedagogical project in } \\
\text { the school. The argumentative process } \\
\text { developed in the reflective sessions } \\
\text { helped the participants' organization of } \\
\text { ideas, their initiative in the decision } \\
\text { making process, and consequently the } \\
\text { construction of the participants reflecti- } \\
\text { ve thinking. }\end{array}$ \\
\hline $\begin{array}{l}\text { PALAVRAS-CHAVE: } \\
\text { continuada formação } \\
\text { Interdisciplinaridade. Argumentação. }\end{array}$ & $\begin{array}{l}\text { KEYWORDS: Continuing teacher } \\
\text { education. } \\
\text { Argumentation. }\end{array}$ \\
\hline
\end{tabular}

\section{Introdução}

Programas de formação continuada de professores têm procurado propor reflexões que, em última instância, subsidiem o desenvolvimento de uma prática pedagógica crítica e socialmente contextualizada, questionando a alienação sobre as ações de ensinar e aprender (LIBERALI, 2012; CRISTÓVÃO, 2005; MAGALHÃES, 2002; MOTTA-ROTH, 2006, entre outros). Isso significa dizer que esse exercício reflexivo pode contribuir para a reconfiguração do papel docente, transformando esse profissional em agente "de transformação do contexto profissional" (CELANI, 2002, p. 24) e, consequentemente, em "multiplicador de ações transformadoras" (SILVA, 2014, p. 20). 
Dentro dessa perspectiva, as pesquisas desenvolvidas pelo Núcleo de Estudos Colaborativos (Necce) buscam oferecer aos professores e pesquisadores espaços de discussão e reflexão que possam levar à reconfiguração de seus papéis como pesquisadores críticos de suas próprias práticas (MAGALHÃES, 2002, p. 42). A exemplo disso, este trabalho objetiva analisar o processo crítico-argumentativo desencadeado em um programa de formação continuada com vistas à problematização do conceito de interdisciplinaridade e ao desenvolvimento de um projeto pedagógico interdisciplinar por professores de uma escola pública de Ensino Fundamental e Educação de Jovens e Adultos (EJA) - doravante denominada de Cell - da cidade de Santa Maria, no estado do Rio Grande do Sul.

Para discutirmos o processo argumentativo desencadeado no referido programa de formação continuada, lançamos mão do conceito proposto por Leitão (2008) com base em Van Eemeren e Gootendorst (2009). Por meio dessa perspectiva argumentativa, discutida na seção 2 deste artigo, exploramos a natureza dual de negociação e mudança da argumentação como recurso epistêmico de mediação de conhecimento, fundamental em processos reflexivos e formativos com vistas à transformação de conceitos e práticas de ensino. No caso específico do processo formativo discutido neste artigo, destacamos que a formação continuada tinha por objetivo desenvolver uma proposta de ensino interdisciplinar. Por essa razão, na seção 3 discutimos o conceito de interdisciplinaridade que subsidiou a configuração dessa proposta de ensino.

\section{O processo argumentativo como ferramenta de negociação de pontos de vista}

Entendemos a argumentação como uma discussão crítica na qual pontos de vista são "construídos, negociados e transformados" (DE CHIARO; LEITÃO, 2005, p. 351). Logo, vemos a argumentação não somente como a expressão de uma avaliação individual, mas como uma contribuição para o processo comunicativo entre pessoas 
ou grupos que trocam ideias com o propósito de deliberar sobre as suas diferenças de opinião (VAN EEMEREN; GOOTENDORST, 2009, p. 55).

Para dar conta de processos de negociação, Compiani (1996, p. 48), em sua pesquisa, discute seis ações discursivo-argumentativas de caráter epistêmico que tendem a elucidar procedimentos explicativos que, em última instância, podem levar à construção e à transformação do conhecimento. Essas ações, igualmente adotadas nesta investigação, foram utilizadas por Compiani para verificar como professores e alunos evoluíam conceitualmente em suas aulas. São elas: 1) a solicitação de informações, que pode ser dividida em clarificação e explicação; a clarificação é acionada quando o interlocutor necessita que alguma ideia exposta seja explicitada novamente, já a explicação, quando uma ideia é exposta, porém faltam as explicações sobre ela; 2) a categoria de fornecimento de informações, que pode ser dividida em: a) exposição simples, b) com pistas e c) remodelamento. A exposição simples envolve novas informações sendo desenvolvidas com base em uma problematização. Já a exposição com pistas visa dar voz às contribuições do interlocutor a partir de pistas fornecidas que levem à construção do conhecimento. Por fim, o remodelamento visa à reelaboração de ideias já mencionadas pelos falantes a fim de aproximá-las dos significados científicos do assunto em debate; 3) a problematização, que envolve a reflexão em torno de um problema colocado em pauta; 4) a reestruturação, que é a reorganização ou sistematização das ideias da discussão; 5) a recondução, que abarca a retomada de algum aspecto da discussão para reforçá-la; e, finalmente, 6) o reespelhamento, que reforça uma ideia construída na discussão por meio de repetição, reformulação ou extensão da ideia.

Desse modo, adotamos a argumentação não apenas pelo seu caráter discursivo, mas por se tratar de uma ferramenta teórico-metodológica que possibilita a mediação do processo de construção do conhecimento socialmente situado (DE CHIARO; LEITÃO, 2005; LEITÃO, 1999, por exemplo). Por essa razão, De Chiaro e Leitão (2005, 
p. 350) destacam as duas características definidoras da argumentação: a negociação e a mudança. A ênfase sobre a negociação e a mudança confere à argumentação uma dimensão epistêmica que a institui "como recurso privilegiado de mediação em processos de construção do conhecimento que ocorrem em contextos sociais diversos" (LEITÃO, 1999, 2000). As autoras ainda complementam que é essa dimensão epistêmica que remete a possibilidades de construção e transformação de crenças e conceitos (LEITÃO, 1999). Assim, debruçamo-nos sobre o caráter epistêmico da argumentação a fim de perceber em que medida houve uma apropriação do

conhecimento pelos participantes da pesquisa no desenvolvimento do projeto interdisciplinar em foco. A seguir, discutimos o conceito de interdisciplinaridade que subsidiou a construção da proposta de ensino desenvolvida no programa de formação continuada.

\section{O conceito de interdisciplinaridade discutido via argumentação}

A prática interdisciplinar estimula a "construção de novos paradigmas de ciência e conhecimento e a elaboração de novos projetos para a educação, a escola e a vida" (GODOY, 2006, p. 32). Levando essa premissa em consideração, ao desenvolvermos a formação continuada na Cell, compreendemos que trabalhar interdisciplinarmente significaria trabalhar colaborativamente, por meio de questionamentos que promovessem a reflexão e a ação sobre o contexto escolar. Nesse sentido, o conceito de interdisciplinaridade não se restringe à interação entre disciplinas. Em outras palavras, acreditamos que as relações interdisciplinares devam acercar-se de um redimensionamento epistemológico e de (re)formulações das estruturas pedagógicas de ensino (GONÇALVES, 1994 apud GODOY, 2006, p. 36).

Para tanto, ao construirmos o projeto interdisciplinar na Cell, consideramos o conjunto de três planos distintos que constituem a interdisciplinaridade escolar: o plano curricular, o plano didático e o plano pedagógico. A interdisciplinaridade 
curricular, sendo o primeiro nível do sistema da interdisciplinaridade escolar, consiste na organização sistemática dos planos de estudos de todas as disciplinas da escola, mantendo cada disciplina uma função específica no currículo (LENOIR, 2008, p. 5758). Já a interdisciplinaridade didática, o segundo nível, é mediadora entre planos curriculares e pedagógicos, e tem por objetivo a articulação dos conhecimentos a serem ensinados e sua inserção em situações de aprendizagem. Por fim, a interdisciplinaridade pedagógica diz respeito à prática em sala de aula, ou seja, ao desenvolvimento das atividades didáticas (construídas no segundo plano e estabelecidas no primeiro) com os educandos. Sendo o terceiro nível da interdisciplinaridade escolar, o plano pedagógico assegura a concretização dos planejamentos interdisciplinares no contexto de aprendizagem em sala de aula (LENOIR, 2008).

A seguir, na seção 4, descrevemos como a proposta de formação continuada foi configurada, apresentando seus participantes e os procedimentos de coleta e análise dos dados analisados neste artigo.

\section{Metodologia}

Neste artigo, discutimos o processo argumentativo de construção de um projeto pedagógico interdisciplinar na Cell, o qual foi constituído discursiva e colaborativamente pelos participantes por meio de sessões reflexivas. Compreendemos as sessões reflexivas como constituidoras de redes de significados potenciais (HALLIDAY, 1989, p. 10). Em última instância, as sessões congregam as escolhas semânticas que emergem do discurso das professoras da Cell sobre interdisciplinaridade no processo interativo/argumentativo desenvolvido ao longo de 2013

Essas sessões reflexivas tinham caráter teórico e prático e aconteciam a cada quinze dias na escola Cell. Nas sessões teóricas, com base em leituras prévias sobre 
interdisciplinaridade, mediávamos a discussão sobre o conceito de interdisciplinaridade e a prática desta em sala de aula. Nas sessões práticas, procuramos sistematizar o projeto interdisciplinar e a produção de uma unidade pedagógica interdisciplinar. Inicialmente, a unidade didática seria construída para uma turma específica da Cell, o $6^{\underline{0}}$ ano B. No decorrer das sessões reflexivas, a proposta foi estendida para as séries iniciais e para os alunos matriculados na Educação de Jovens e Adultos (EJA), tendo em vista que participavam da formação continuada professoras que atuavam também nos referidos contextos.

\subsection{Contexto de investigação e participantes}

A Cell é uma escola pública de Ensino Fundamental e EJA localizada em uma comunidade de baixa renda do município de Santa Maria, RS. Ela busca engajar as famílias dos alunos nas atividades da escola a fim de aproximar a comunidade, bem como de melhorar a qualidade do ensino oferecido (SILVA, 2014, p. 53).

Em relação aos participantes, destacamos que iniciamos a formação continuada em abril de 2013, com 15 professoras de diferentes disciplinas, e a finalizamos em novembro de 2013, com 12 participantes (percentual de 18 \% de desistência). Todas as professoras da Cell possuem graduação na sua área de atuação e algumas atuam em diferentes níveis de ensino. Além das professoras da Cell, contamos com duas professoras mediadoras da UFSM. As professoras mediadoras eram oriundas do curso de Letras-Inglês da mesma universidade e tinham a função de mediar o processo reflexivo-argumentativo desenvolvido no programa de formação continuada. A partir do segundo semestre de 2013, contamos também com a participação de 13 alunos de graduação em Letras-Inglês da UFSM. Esses alunos estavam matriculados em uma Disciplina Complementar de Graduação (DCG), que tinha por objetivo a produção de material didático no/para o contexto da escola pública, desenvolvido em programas de formação continuada. Assim, no decorrer do processo reflexivo, os professores 
mediadores, as professoras da Cell e os alunos de graduação fizeram leituras teóricas e paralelamente confeccionaram uma Unidade Didática interdisciplinar.

Os participantes dessa investigação estão sinalizados no texto com as seguintes iniciais: (P) para os professores participantes, $(\mathrm{M})$ para as mediadoras da formação continuada, e $(\mathrm{G})$ para os alunos de graduação participantes do projeto.

\subsection{Procedimentos de coleta e análise dos resultados}

Realizamos, no contexto da escola investigada, 17 sessões reflexivas. Essas sessões foram desencadeadas quinzenalmente, no decorrer de 2013, no horário das reuniões pedagógicas regulares da escola. Cada sessão compreendeu, em média, de 1h30min a $2 \mathrm{~h}$ de gravação em vídeo. Para este artigo, selecionamos três sessões reflexivas destacadas no Quadro 1.

Quadro 1 - Identificação, data, duração e atividades desenvolvidas nas sessões reflexivas.

\begin{tabular}{|c|c|c|c|}
\hline $\begin{array}{c}\text { Identificação da } \\
\text { sessão reflexiva }\end{array}$ & Data & $\begin{array}{c}\text { Tempo de } \\
\text { duração }\end{array}$ & Atividades desenvolvidas \\
\hline SR\#2 & $9 / 5 / 2013$ & 59 minutos & $\begin{array}{c}\text { Discussão sobre a proposta de um } \\
\text { projeto interdisciplinar }\end{array}$ \\
\hline SR\#4 & $6 / 6 / 2013$ & $\begin{array}{c}1 \text { hora } 49 \\
\text { segundos }\end{array}$ & $\begin{array}{c}\text { Discussão do conceito de } \\
\text { interdisciplinaridade com base em } \\
\text { Lenoir (2008) }\end{array}$ \\
\hline SR\#13 & $24 / 10 / 2013$ & $\begin{array}{c}47 \text { minutos } 14 \\
\text { segundos }\end{array}$ & $\begin{array}{c}\text { Desenvolvimento de atividades } \\
\text { didáticas com base nos conceitos } \\
\text { discutidos de }\end{array}$ \\
interdisciplinaridade
\end{tabular}

A fim de mostrar como o projeto interdisciplinar tomou forma na escola Cell, optamos por fazer a análise da SR \#2, que destaca o início desse projeto, quando as primeiras ideias sobre a construção de um projeto interdisciplinar foram discutidas pelas participantes. A SR \#4 evidencia o debate teórico sobre a representação de interdisciplinaridade e sobre a prática interdisciplinar das professoras. Por fim, a SR 
\#13 apresenta o processo da constituição das atividades didáticas que permearam o projeto interdisciplinar na Cell.

Para a análise do processo argumentativo desenvolvido no contexto escolar com vistas à problematização do conceito de interdisciplinaridade e de prática interdisciplinar, consideramos a Argumentação (COMPIANI, 1996; LEITÃO, 2007b, 2011) como ferramenta de análise.

Assim, primeiro identificamos os momentos de discussão mais representativos da configuração e do desenvolvimento do projeto interdisciplinar em cada sessão reflexiva. Em seguida, levando em consideração os excertos selecionados, identificamos e classificamos, nas falas das professoras, as ações discursivoargumentativas que procuravam elucidar procedimentos explicativos e que, em última instância, levassem à construção e à transformação do conhecimento (PONTECORVO; GIRARDET, 1993).

A classificação das ações discursivo-argumentativas teve como base seis categorias de análise utilizadas por Compiani (1996) e discutidas na seção 2.1. Além disso, incluímos duas novas categorias a fim de melhor elucidar os nossos resultados. São elas: acolhimento e refutação.A categoria de acolhimento envolve a aceitação de uma ideia colocada em discussão. O Acolhimento pode fundar-se em uma problematização, em uma reestruturação da discussão, em uma recondução desta, bem como no reespelhamento de uma ideia. Nesse sentido, o acolhimento funciona como uma aprovação do discurso do outro. Por outro lado, a categoria de refutação envolve a contestação e/ou a reprovação de uma ideia da discussão. A refutação também pode ser evidenciada após uma problematização, uma reestruturação, uma recondução ou um reespelhamento. No Quadro 2, destacamos as categorias de análise utilizadas para a investigação do processo argumentativo nas sessões reflexivas. 
Quadro 2 - Categorias de análise das sessões reflexivas com base em Compiani (1996).

\begin{tabular}{|c|c|}
\hline \multicolumn{2}{|c|}{ Ações discursivo-argumentativas } \\
\hline & Subcategoria \\
\hline \multirow[t]{2}{*}{ 1. Solicitação de informações } & 1A. Clarificação \\
\hline & 1B. Explicação \\
\hline \multirow[t]{3}{*}{ 2. Fornecimento de informações } & 2A. Exposição simples \\
\hline & 2B. Exposição com pistas \\
\hline & 2C. Remodelamento \\
\hline 3. Problematização & - \\
\hline 4. Reestruturação & - \\
\hline 5. Recondução & - \\
\hline 6. Reespelhamento & - \\
\hline $\begin{array}{l}\text { 7. Acolhimento (da problematização, da } \\
\text { reestruturação, da recondução, do reespelhamento) }\end{array}$ & - \\
\hline $\begin{array}{l}\text { 8. Refutação (da problematização, da reestruturação, } \\
\text { da recondução, do reespelhamento) }\end{array}$ & - \\
\hline
\end{tabular}

\section{Resultados}

\section{$5.1 \mathrm{O}$ "pontapé" inicial na construção do projeto interdisciplinar}

Na primeira sessão (SR \#2) analisada, podemos identificar o momento no qual a proposta de construção de um projeto de ensino interdisciplinar emerge do/no processo reflexivo. As participantes problematizam essa ideia, a começar por P4, que é professora da Cell, ao fazer a sugestão e, na sequência, remodelar sua proposta inicial, procurando aproximá-la de uma proposta pedagógica de ensino (e que fosse situado para todas as disciplinas) no momento em que recebe o acolhimento da ideia por M2 (Excerto 1). 
Excerto 1

\begin{tabular}{|c|c|}
\hline Exemplo do corpus & $\begin{array}{c}\text { Categoria } \\
\text { argumentativa }\end{array}$ \\
\hline $\begin{array}{l}\text { P4- Não sei se os professores juntos a gente podia fazer algo em torno } \\
\text { de um tema que pudesse servir para nós como um projeto } \\
\text { interdisciplinar. }\end{array}$ & Problematização \\
\hline M2- Ta bom. & Acolhimento \\
\hline P4- e que esse fosse então situado para todas para as disciplinas. & Remodelamento \\
\hline M1- Uhum & Acolhimento \\
\hline $\begin{array}{l}\text { P4- seria uma sugestão para que a gente tenha uma atividade que } \\
\text { realmente seja diferente do que aquilo que cada um preparou seu e deu } \\
\text { né e que seja interdisciplinar, que convirja para um projeto maior na } \\
\text { escola que é construir uma cultura de saúde e paz e nesse projeto eu } \\
\text { acredito que todos né nessa proposta todas as disciplinas tem como se } \\
\text { envolver. }\end{array}$ & Reestruturação \\
\hline M2- Uhum & Acolhimento \\
\hline $\begin{array}{l}\text { P4- né que então dentro disso que poderia cada professor ver na sua } \\
\text { área que conteúdo poderia ser trabalhado. }\end{array}$ & Reestruturação \\
\hline M1- A partir de uma temática mais geral. & Reespelhamento \\
\hline $\begin{array}{l}\text { P4-É, eu sugiro que seja assim para que não fique tudo solto como se a } \\
\text { gente já faz toda essa falta de tempo de se reunir para fazer um projeto } \\
\text { mais coeso e mais que seja mais coletivo e nesse momento a gente } \\
\text { poderia aproveitar. }\end{array}$ & Reestruturação \\
\hline P7- Para que não fique ações isoladas né. & Reespelhamento \\
\hline P2- É, é coletivo. & Reespelhamento \\
\hline
\end{tabular}

No Excerto 1, a problematização de P4 inicia quando ela sugere às outras professoras que trabalhem "em torno de um tema" a fim de construir um projeto interdisciplinar. Essa fala de P4 sustenta a importância que a professora dá ao trabalho colaborativo: "professores juntos", "servir para nós”. Nesse sentido, também podemos observar, por meio do discurso de P4, uma visão de interdisciplinaridade como comunicação entre as disciplinas, "para todas as disciplinas", a fim de estudarem um tema específico, orientado pelo contexto em questão (GODOY, 2006). As mediadoras M1 e M2 concordam com a proposta, por meio do acolhimento, ao mesmo tempo em que M1 sistematiza a fala de P4 e sinaliza que essa sugestão pode ser aproveitada para o projeto geral da escola: “Construindo uma cultura de saúde e paz". 
Partindo de sua problematização acerca da realização da proposta de ensino interdisciplinar no contexto escolar, P4 traz novas informações para a proposta do projeto interdisciplinar ao mencionar que cada professor pode analisar seus conteúdos programáticos e perceber quais podem ser utilizados no projeto. M1 concorda com P4 e, por reespelhamento, reforça e reformula a ideia da temática. Ainda debatendo sobre a ideia do projeto interdisciplinar, $\mathrm{P} 4$ expande seu argumento de que o projeto deve ser feito colaborativamente, pois a falta de tempo dos professores não lhes permite realizar atividades de tal cunho. $\mathrm{P} 4$ ainda reitera que o espaço da formação continuada é o momento propício para a construção colaborativa de conhecimento. Posteriormente à fala de $\mathrm{P} 4$, percebemos o acolhimento do grande grupo quanto à realização do projeto interdisciplinar, pois as professoras P7 e P2 reforçam, por meio do reespelhamento (da reformulação e do reforço da ideia inicial), o aspecto colaborativo do projeto interdisciplinar proposto por P4 ao mencionarem que as ações do projeto não devem ser "isoladas", mas "coletivas".

Com o propósito de entender a organização da negociação discursiva entre as professoras durante as sessões reflexivas, procuramos identificar a sequência argumentativa de cada sessão. Segundo Magalhães (2011, p. 20), é a partir da identificação da organização argumentativa que podemos "mapear como os participantes escutam uns aos outros, retomam as falas uns dos outros para concordar, inserir novos temas, pedir esclarecimento, completar o que foi dito".

Dessa maneira, ao observar a organização argumentativa do Excerto 1, podemos perceber que o "pontapé" inicial do projeto interdisciplinar surge a partir da problematização de $\mathrm{P} 4$, que, ao receber o acolhimento da ideia pelo grande grupo (mediadoras e professoras), dá forma à sua problematização, sistematizando-a por meio da reestruturação. As demais participantes, por sua vez, ao acolherem a proposta, trabalham discursivamente na sua elaboração por meio do reespelhamento. A Figura 1 
ilustra essa organização argumentativa que dá início ao projeto interdisciplinar na escola Cell.

Figura 1 - Exemplo da sequência argumentativa da SR \#2: o lançamento do projeto pedagógico interdisciplinar.

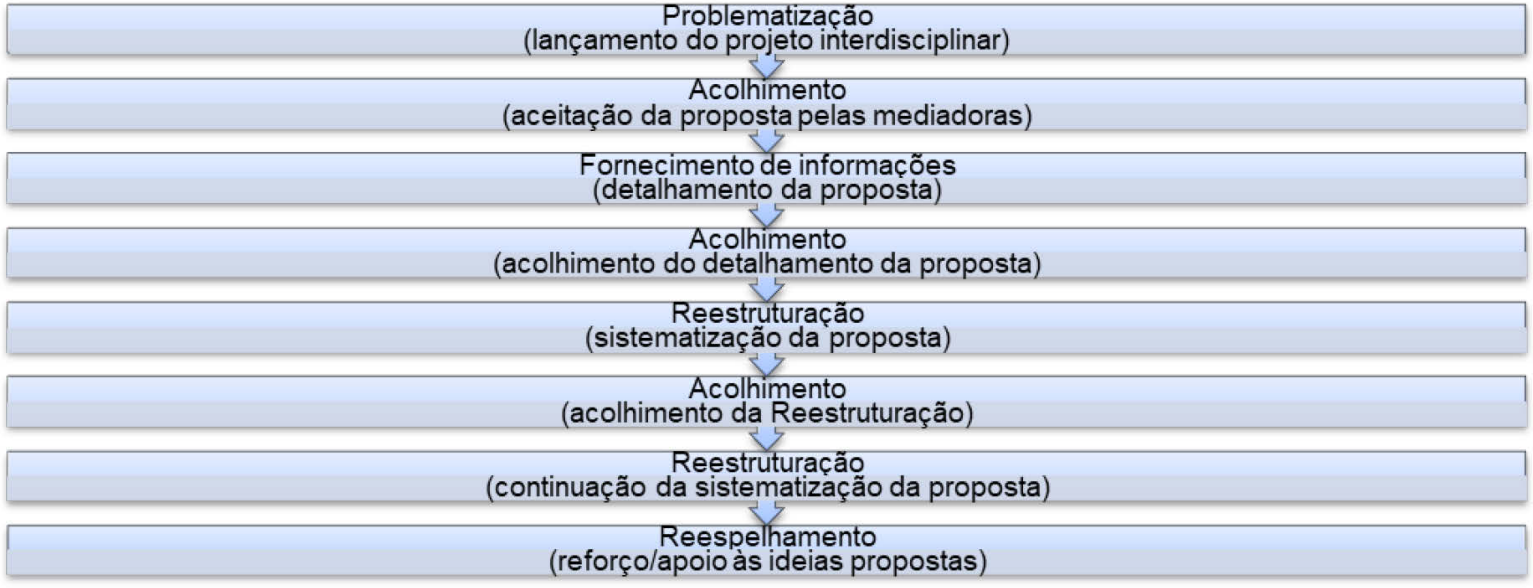

A fim de mapear os dados da primeira sessão reflexiva analisada, na Tabela 1, com base em Compiani (1996), evidenciamos as ações discursivo-argumentativas encontradas e as suas recorrências na SR \#2.

Tabela 1 - Recorrência das ações discursivas na SR \#2.

\begin{tabular}{l|c|c}
\hline \multicolumn{3}{c}{ SR \#2 - O "pontapé” inicial da proposta interdisciplinar } \\
\hline \multicolumn{3}{c}{ Ações discursivo-argumentativas } \\
\hline \multirow{2}{*}{$\begin{array}{l}\text { 1. Solicitação de } \\
\text { informações }\end{array}$} & Subcategoria & Recorrência no discurso \\
\hline 2. Fornecimento de & 1A. Clarificação & 4 \\
informações & 1B. Explicação & 4 \\
\cline { 2 - 3 } & 2A. Exposição simples & 9 \\
\cline { 2 - 3 } & 2B. Exposição com pistas & 0 \\
\hline 3. Problematização & 2C. Remodelamento & 4 \\
\hline 4. Reestruturação & - & 6 \\
\hline 5. Recondução & - & 2 \\
\hline 6. Reespelhamento & - & 6 \\
\hline 7. Acolhimento & - & 0 \\
\hline 8. Refutação & & 14 \\
\hline
\end{tabular}


Ao observarmos as categorias mais recorrentes na SR \#2, percebemos que a categoria de reespelhamento se sobressai. Em nossa opinião, isso se deve ao fato de que as professoras, com base em uma problematização ou em novas informações que são colocadas em pauta, tendem a reformular e/ou ampliar as ideias de suas colegas a fim de apoiá-las e de dar início à construção do projeto interdisciplinar. Acreditamos também que, por esse motivo e por estarmos discutindo a construção inicial do projeto, temos uma recorrência de reestruturações e exposições simples, isto é, de novas informações sendo colocadas em pauta e sistematizadas para serem aceitas (ou não) pelo grande grupo. Em última instância, essas ações discursivas tiveram o propósito de moldar o projeto interdisciplinar. No caso da SR \#2, as reestruturações e as exposições simples foram, em todas as ocasiões, acolhidas pelo grande grupo.

\subsection{As discussões teóricas que embasaram o projeto}

O debate teórico durante a SR \#4 foi realizado com base na leitura do artigo de Lenoir (2008). O Excerto 2 exemplifica o início do debate, no momento em que M1 lança uma problematização às professoras. M1 tem como objetivo levar as professoras à reflexão sobre o conceito de interdisciplinaridade, partindo da prática docente das participantes antes de refletirem sobre o conceito proposto por Lenoir. Nesse sentido, podemos perceber que M1, por meio da problematização, procura levar as professoras à confrontação de suas possíveis concepções iniciais de interdisciplinaridade, considerando também as perspectivas discutidas no texto em questão (LEITÃO, 2000 apud LEITÃO, 2007a, p. 82). 
M1-[...] antes de a gente começar a discutir o texto propriamente... Problematização pensando na prática de vocês e no conceito de interdisciplinaridade que vocês já tem, né... por meio da prática de vocês, o quê que vocês poderiam dizer, "eu acho que interdisciplinaridade é isso". Vocês podem lembrar do questionário da primeira semana, né, que vocês responderam. E quem conseguiu ler o texto mais a fundo, então, mudou alguma concepção? $O$ que tinha... eu acho que interdisciplinaridade é isso, agora lendo esse texto mudou um pouco. $E$ aí, o que vocês entendem por interdisciplinaridade, partindo da prática?

P2- [VOZES] Eu acho que até mesmo sem querer a gente pratica né? Eu acho que... a intenção é praticar porque há anos a gente vem com a ideia de interdisciplinaridade...eu mesmo interdisciplinaridade eu acho que eu trabalho desde 2000, né... claro que ao longo do tempo ela vem reformulando, eu mesmo aprendi do ano passado para cá várias coisas, assim que... pra mim... eu achava que matemática, eu colocaria ali um mapa e... vamos estudar densidade demográfica, e eu tava...colocando com geografia e a partir do momento... e eu primeiro...e pra mim era só geografia e daí eu vi que não, também trabalha história, né? Então, assim eu vi que ao longo dos anos, até nos cursos que a gente faz, nos livros que a gente lê, nos textos, a gente vem intensificando mais a interdisciplinaridade. E eu acho que ela já faz parte do cotidiano da gente né, gurias? Porque tudo...tudo tá envolvido, né?

P5- No meu próprio livro didático, né, já é assim, tudo junto né. Os Reespelhamento textos assim pra trabalhar, os exercícios, todos eles já tá tão.

Logo após a problematização de M1, que está mediando a sessão, P2, com uma exposição simples, comenta que já percebe a interdisciplinaridade presente em sua prática docente há alguns anos. Identificamos, nessa fala, que P2 compreende a interdisciplinaridade como algo intrínseco ao contexto escolar. Podemos perceber então que a representação de interdisciplinaridade de P2 não pressupõe trabalho pedagógico conjunto com outros docentes (FAZENDA, 2005), mas de prática individual, a qual congrega diferentes disciplinas. Na fala seguinte à de P2, a professora P5, por meio de reespelhamento, expande a exposição simples da colega alinhando-se também à representação de interdisciplinaridade como algo já 
incorporado ao sistema escolar, exercida individualmente pelo professor ao adotar o livro didático que traz atividades interdisciplinares. Em relação à organização argumentativa de SR \#4, temos a seguinte configuração até o momento (Figura 2).

Figura 2 - Exemplo de sequência argumentativa da SR \#4: argumentos de acolhimento.

\begin{tabular}{|c|}
\hline Problematização \\
\hline Fornecimento de informação: Exposição simples e/ou \\
\hline Acolhimento e/ou \\
\hline Reespelhamento \\
\hline
\end{tabular}

A discussão em SR \#4 é instaurada com uma problematização lançada pelas mediadoras e pelas professoras. Em seguida, essas problematizações vêm acompanhadas de exposições simples, acolhimentos e/ou reespelhamentos. Nesse sentido, podemos considerar que a ação discursivo-argumentativa de "problematizar" tem como intenção "iniciar, instigar e provocar momentos de procura de respostas para um problema colocado" (COMPIANI, 1996, p. 45) a partir da troca colaborativa de ideias e de sugestões, no nosso caso, para questões teóricas sobre interdisciplinaridade.

Notamos que, até o momento, no decorrer do processo argumentativo, as ideias apresentadas na configuração do projeto interdisciplinar na Cell vinham sendo acolhidas pelas participantes. É desse ponto em diante que começamos a identificar momentos de questionamento da viabilidade de desenvolvimento de um projeto interdisciplinar no contexto escolar, como exemplifica o Excerto 3. 
M1-[...] daí o Leffa que é da área da Linguística... ele vai fazer uma Problematização comparação das disciplinas fechadinhas como se fossem gavetas... [...] que era o que a gente tava falando, se não me engano no outro encontro da questão da zona de conforto né...vou ficar só com o meu conteúdo aqui... "ah eu vejo que isso eu posso fazer interdisciplinaridade com o professor de matemática, mas vai dar muito trabalho, então eu vou ficar no meu cantinho"... bem interessante essa metáfora que ele traz né. P11- É, mas às vezes não é só porque não quer dar trabalho né, mas porque para um professor de escola pública... trabalho significa trabalho... a gente vai pra casa dorme $2 h$ da manhã, levanta às $6 h . . . e$ é assim todos os dias... $e$ as vezes não tem final de semana porque tem prova pra corrigir trabalho pra corrigir... prova pra fazer...

M1- [VOZES] A gente leva trabalho pra casa né. Acolhimento/ Reespelhamento

P11- a interdisciplinaridade nãa [ênfase na palavra] se dá por conta da Reespelhamento falta de tempo... essa falta de tempo não é brincadeira.

M2- é que na verdade o planejamento deveria ter mais horas...

Exposição

simples

No Excerto 3, M1 guia a discussão sobre o texto de Lenoir (2008) e explicita que na perspectiva disciplinar tradicional cada disciplina é responsável por um conteúdo específico, sem propor comunicação com conteúdos de outras áreas. Para isso, M1 traz uma citação de Leffa (2006), que compara metaforicamente as disciplinas estanques aos feudos da Idade Média, nos quais "qualquer conhecimento produzido fica retido dentro dos muros de proteção". Ao trazer a voz de Leffa, M1 procura recuperar a cultura tradicionalmente individualista da organização escolar e do professor. Todavia, P11 refuta a problematização de M1 e argumenta que é a falta de tempo do professor que atua no ensino público que muitas vezes o impede de trabalhar interdisciplinarmente em sala de aula. E são inúmeras as dificuldades vivenciadas pelo profissional que atua na educação básica: dos baixos salários à carga de trabalho excessiva, passando pela falta de infraestrutura das escolas. 
Apesar de vivenciarem todas essas dificuldades, as professoras da Cell aceitam o desafio de buscar mudanças em sua formação docente por meio da formação continuada (MELLO; DUTRA, 2011, p. 81). Percebemos essa característica nas professoras logo no início do projeto na Cell. Na terceira sessão reflexiva, as professoras argumentam que seria mais relevante para o seu contexto de ensino se construíssemos um projeto interdisciplinar com foco em uma turma específica da escola, na qual as professoras vivenciavam dificuldades de participação e de envolvimento por parte dos alunos. Assim, atividades pedagógicas interdisciplinares foram colaborativamente planejadas e produzidas em 2013, e compiladas em um caderno didático (TICKS; BRUM; SILVA, 2014). Essas atividades foram aplicadas pelas professoras ao longo de 2014, e a produção dos alunos foi igualmente incluída no referido caderno. Dessa maneira, ao fazerem uso da autonomia e da responsabilidade ao refletirem sobre seu contexto de ensino, as professoras "tomaram as rédeas" de sua própria formação continuada, visando à transformação dos problemas vivenciados naquele momento na escola Cell.

Por essa razão, ao receber a Refutação de P11, M1 tenta considerar a colocação da participante e, por reespelhamento, reforça o pensamento de P11 de que os professores realmente possuem muito trabalho e pouco tempo para organizá-lo. Em seguida, P11 ainda reforça sua refutação afirmando que a interdisciplinaridade não acontece exclusivamente pela falta de tempo do professor. O discurso de P11 revela a complexidade que representa o contexto escolar, marcado

pela heterogeneidade dada pelas diferentes representações (teorias de uso ou formais) trazidas pelos interagentes (professores, coordenadores, diretores, alunos e pais) em diferentes domínios: compreensão de papéis, dos sentidos a serem construídos, dos objetivos a serem atingidos e de como atingi-los, bem como das diferentes capacidades necessárias àquela situação particular (MAGALHÃES, 2002, p. 41). 
Ainda no Excerto 3, M2, por meio de uma exposição simples, sugere que os horários de planejamento sejam mais extensos, o que seria uma possível solução para a falta de tempo do professor. Todavia, P11 parece também refutar a colocação de M2 ao mencionar que o planejamento não pode ser considerado como uma atividade docente e ainda expande sua refutação relatando o caso de professores que lecionam em mais de uma escola.

Vale lembrar que, na representação inicial de P2 (no Excerto 2), a interdisciplinaridade é vista como intrínseca às séries iniciais, pois várias áreas do conhecimento precisam ser mobilizadas para o planejamento das aulas, já que as matérias escolares ainda não estão divididas em disciplinas. P11, ao contrário, é responsável por uma disciplina específica na escola, admite não praticar a interdisciplinaridade e, para fazê-la, compreende que precisaria trabalhar com outros professores, entretanto, por falta de tempo e excesso de trabalho isso não acontece. Nesse sentido, podemos perceber que o processo argumentativo evidenciou diferentes concepções de interdisciplinaridade e um lócus específico no contexto escolar no qual ela é vivenciada, permitindo "exame, compreensão e apropriação de uma multiplicidade de posições sobre um mesmo tema" (LEITÃO, 2011, p. 42).

No que se refere especificamente às refutações de P11, embora reconheçamos que a rotina do professor do Ensino Básico Estadual seja realmente estressante e desgastante, entendemos igualmente que as refutações revelam a difícil tarefa de refletir sobre essas dificuldades em um processo formativo e continuado. Muitas vezes, a formação coloca em debate crenças, valores, perspectivas de ensino e de aprendizagem que fazem parte de uma cultura escolar irreflexiva (GODOY, 2006, p. 33).

Na sequência argumentativa anterior (Figura 2), vimos que há uma recorrência de problematizações que são, via de regra, acolhidas e, então, sofrem reespelhamento e acréscimo de informações por exposição simples. Em relação à sequência do Excerto 3 
(Figura 3), podemos evidenciar que as refutações no discurso das professoras são resultado de seu estranhamento ao conhecimento acerca do conceito de interdisciplinaridade proposto no processo reflexivo. Essas contraposições, ao instalarem momentos de conflito, auxiliam na consideração de diferentes pontos de vista sobre a prática interdisciplinar, abrindo espaço para a construção do pensamento reflexivo e, em última instância, de um horizonte de possibilidades de ação e de mudança dos contextos em questão (DAMIANOVIC; LEITÃO, 2012, p. 157).

Figura 3 - Exemplo de sequência argumentativa da SR \#4: argumentos de refutação.

\begin{tabular}{|c|}
\hline Problematização \\
\hline $\begin{array}{c}\text { Refutação } \\
\text { (da Problemătização) }\end{array}$ \\
\hline $\begin{array}{c}\text { Acolhimento } \\
\text { (da Refutação) }\end{array}$ \\
\hline Reespelhamento \\
\hline Fornecimento de informações: Exposição Simples \\
\hline Refutação \\
\hline
\end{tabular}

Em resumo, ainda que durante a discussão da SR \#4 as professoras tenham refutado a problematização proposta pelos pesquisadores argumentando acerca das dificuldades logísticas do trabalho interdisciplinar com outros colegas, elas não abandonaram a ideia de implementar tal proposta. Tais conflitos podem inclusive ter contribuído no processo de transposição de barreiras disciplinares e no engajamento no trabalho coletivo de construção do caderno didático, o qual foi o produto final do processo de formação continuada na escola Cell. Levando isso em consideração, podemos perceber que os exemplos retirados da SR \#2 e SR \#4 nos mostraram que o envolvimento das professoras no projeto interdisciplinar também promoveu a construção de agência das participantes, e, ainda, levou à negociação e à reorquestração de suas ações futuras dentro do projeto (DAMIANOVIC, 2011, p. 281). 


\subsection{O desenvolvimento do projeto pedagógico interdisciplinar pelas participantes}

Nesta seção, discutimos a sessão reflexiva (SR \#13) que sucedeu os encontros teóricos sobre interdisciplinaridade. Tal sessão teve como objetivo planejar e produzir colaborativamente uma unidade didática interdisciplinar produzida para os alunos do $6^{\circ}$ ano B do Ensino Fundamental da Cell. Vale lembrar que, no decorrer das sessões reflexivas, outras unidades didáticas foram produzidas também para as séries iniciais e para os alunos matriculados na Educação de Jovens e Adultos (EJA), uma vez que participavam da formação continuada professoras que atuavam também nos referidos contextos.

As professoras responsáveis pelas disciplinas de Educação Física, Espanhol e Matemática do $6^{\circ}$ ano decidiram explorar, como tema da unidade, o esporte tênis de mesa. Esse esporte foi escolhido pelo fato de a escola possuir uma mesa de tênis em seu hall e de os alunos, nos intervalos das aulas, aventurarem-se no jogo (Excerto 4). 
Excerto 4

\begin{tabular}{|c|c|}
\hline Exemplo do corpus & $\begin{array}{c}\text { Categoria } \\
\text { argumentativa }\end{array}$ \\
\hline P2- [xxx] Nós fizemos sobre o tênis de mesa. & $\begin{array}{l}\text { Exposição } \\
\text { simples }\end{array}$ \\
\hline M1- Sim. & Acolhimento \\
\hline $\begin{array}{l}\text { P2- Daí só agora ainda não aplicamos porque nem começamos porque o } \\
\text { instrutor não pôde vir. }\end{array}$ & $\begin{array}{l}\text { Exposição } \\
\text { simples }\end{array}$ \\
\hline $\begin{array}{l}\text { P5- E a gente fez a... perguntou para ele o que é o tênis de mesa, qual as } \\
\text { regras, quem participa, o histórico né, de como acontece os jogos, que } \\
\text { países. }\end{array}$ & Reespelhamento \\
\hline $\begin{array}{l}\text { P2- Isso, e na parte de Matemática a gente vai medir a mesa, os padrões, } \\
\text { os utensílios, o que é usado, a bolinha, a raquete. }\end{array}$ & $\begin{array}{l}\text { Exposição } \\
\text { simples }\end{array}$ \\
\hline M1- Uhum & Acolhimento \\
\hline $\begin{array}{l}\text { P2- ... a rede tudo isso a gente colocou e levar eles para sala digital para } \\
\text { eles pesquisarem a Espanha quando participaram de uma Olimpíada né } \\
\text { toda essa... quais os brasileiros que participam do tênis de mesa, de } \\
\text { língua espanhola quantos participam, também entra Geografia, né com } \\
\text { a parte dos países, né até a densidade do Brasil. }\end{array}$ & $\begin{array}{l}\text { Exposição } \\
\text { simples }\end{array}$ \\
\hline
\end{tabular}

No excerto acima, P2 anuncia a temática de sua unidade didática por exposição simples, a fim de relembrar o grande grupo. P2, ao receber a acolhida por parte de M1, continua sua explicação sobre as atividades e justifica que a unidade de seu grupo ainda não teve a oportunidade de ser aplicada em sala de aula. Em seguida, conforme o reespelhamento de P5, o planejamento de uma palestra sobre as regras, a dinâmica e a história do esporte serviriam como atividades introdutórias para a unidade didática. Então, P2, por meio de uma exposição simples, argumenta que, após a palestra, seriam realizadas atividades que abordassem o conteúdo da disciplina de Matemática, por exemplo, o sistema métrico, utilizando os materiais do próprio jogo.

Ainda no Excerto 4, P2 continua sua explicação (impulsionada pelo acolhimento de M1) e relata a relação interdisciplinar nas atividades do grupo. De acordo com a última exposição simples de P2, a disciplina de Espanhol seria abordada na comparação entre Espanha e Brasi, no que se refere às competições e às conquistas do tênis de mesa nesses dois países. Além disso, P2 também menciona uma possível conexão com outra disciplina que não faz parte do seu grupo (Geografia), a fim de trabalhar a densidade 
demográfica dos países abordados. Essa possível conexão com a disciplina de Geografia, sinalizada por P2, reforça o pressuposto "de que cada vez mais se torna necessário aproximarmo-nos das nossas práticas para compreendermos o que fazemos, como fazemos e por que fazemos" (GODOY, 2006, p. 36), observando a interdisciplinaridade como intrínseca ao conhecimento.

Na sequência, o Excerto 5 exemplifica o desenvolvimento das atividades do grupo das professoras de Ciências, História e Geografia. A explicação das atividades é realizada por P4, com uma problematização lançada por M2 no início da SR \#13. Segundo P4, as professoras optaram por comparar as cidades antigas com as cidades modernas, em relação ao tema poluição, pois uma das professoras (P7) já estava trabalhando com esse conteúdo em aula.

\section{Excerto 5}

Exemplo do corpus

P4- É... o nosso grupo ficou com o espaço urbano e rural né e a gente trabalhou com imagens porque a [nome da professora P7] da História está trabalhando as cidades antigas e como era a poluição né do solo com a evolução das cidades né da antiguidade até hoje, o número de população, o quê essa população fez né e como fez e a ocupação desse solo, os problemas que traz, problema de poluição da água, a evolução das cidades como era da antiguidade até hoje né.

G1- É na verdade a gente pensou em começar da realidade deles para Santa Maria. Começar pelas fotos antigas da cidade, como a cidade era né e como a cidade hoje está, da questão da arborização, como que a cidade foi povoada, em questão mesmo de que efeitos isso tem no solo,... Então a gente vai começar pela sua realidade que tá mais presente para eles, e depois como foi para as cidades antigas e assim por diante. Então as professoras disseram que a leitura é algo que é difícil nessa turma, então agente pensou primeiro fazer uma coisa que chamasse mais a atenção deles com imagens e depois introduzindo a leitura aos poucos. Aí escolhemos um vídeo que possa trabalhar com as três disciplinas que é uma animação que mostra desde o início né da ocupação da povoação do mundo como um todo e a representação do homem que vai mudando construindo, que vai desmatando, que vai poluindo e assim por diante.

\section{Categoria}

argumentativa

\author{
Exposição \\ simples
}

Reespelhamento 
A fim de complementar a exposição simples de P4, a aluna do curso de Letras (G1), por meio de reespelhamento, expande a explicação de P4 ao situar que as atividades objetivavam atender à realidade dos alunos. Em outras palavras, ela discute a importância de um planejamento que considere a vida fora das fronteiras escolares (FREIRE, 2003, p. 194) e as diferentes visões de mundo e de realidade dos alunos (MOTTA-ROTH, 2008, p. 245).

G1 ainda coloca que as professoras do grupo haviam mencionado a dificuldade de abordar a habilidade de leitura em sala de aula, e, portanto, iniciariam as atividades de sua unidade com um vídeo de animação sobre o impacto da ação humana no mundo e a produção de lixo que resulta dessa ação, a fim de despertar a atenção dos alunos do $6^{\mathbf{0}}$ ano antes de iniciar a leitura do texto escrito. Nesse sentido, podemos perceber a preocupação das participantes em relação à sensibilização dos alunos ao conteúdo proposto em sala de aula e, em última instância, à construção do conhecimento destes. Da mesma forma, a temática escolhida pelo grupo e a seleção dos textos para a construção das atividades dão indicações de que as participantes estão em consonância com o desenvolvimento do pensamento crítico e com o exercício da cidadania de seus alunos (FREIRE, 2003). Com base na análise da SR \#13, pudemos identificar a seguinte sequência argumentativa para a sessão (Figura 4): 
Figura 4 - Exemplo de sequência argumentativa da SR \#13: relato das atividades.

\begin{tabular}{|c|}
\hline \multicolumn{1}{|c|}{ Problematização } \\
\hline Fornecimento de informação: Exposição Simples \\
\hline Reespelhamento e/ou \\
\hline Acolhimento \\
\hline Fornecimento de informação: Exposição Simples \\
\hline Reespelhamento e/ou \\
\hline Acolhimento \\
\hline \\
\hline Solicitação de informação: Explicação \\
\hline Reespelhamento \\
\hline
\end{tabular}

Observamos que as exposições simples, que relatam o desenvolvimento das atividades, são instigadas pela problematização inicial lançada por M2 no início da sessão reflexiva. Essa problematização tem como objetivo promover o relato dos grupos sobre o trabalho realizado até o presente momento, a fim de perceber de que maneira essas atividades estão sendo construídas e se já foram colocadas em prática na Cell. Cada grupo, ao relatar suas atividades, o faz por meio de exposições simples, as quais são, em alguns momentos, acolhidas pelas mediadoras e/ou pelo grupo, e, em outros, são expandidas por meio de reespelhamento. Este, na maioria dos casos, é realizado pelos membros do próprio grupo de trabalho com o propósito de colaborar com as colocações anteriores dos colegas sobre como as atividades foram desenvolvidas.

Em suma, observamos que a sequência argumentativa parte de uma problematização seguida por uma exposição simples e por um reespelhamento, respectivamente. Percebemos, então, nos excertos da SR \#13, após essa sequência triádica, a repetição de algumas ações discursivas a fim de assegurar a continuidade do relato das professoras, isto é, a exposição de nova ideia incita a aceitação (ou não) desta, bem como a uma expansão ou explicação do que foi previamente dito. 
Ao analisarmos as recorrências das ações discursivas na SR \#13 (Tabela 2), podemos perceber a recorrência de exposições simples seguidas de reespelhamento e de acolhimento, respectivamente. Essa recorrência ao longo da sessão pode ser explicada pelo fato de focalizar o relato das professoras sobre as atividades desenvolvidas. Da mesma maneira, o acolhimento aparece como categoria recorrente na sessão pelo fato de que, na SR \#13, as professoras relatam o desenvolvimento de suas atividades e isso é acolhido pelo grupo.

Tabela 2 - Recorrência das ações discursivas na SR \#13.

SR \#13 - O desenvolvimento do projeto pedagógico interdisciplinar Ações discursivo-argumentativas

\begin{tabular}{l|c|c}
\hline \multirow{2}{*}{$\begin{array}{l}\text { 1. Solicitação de } \\
\text { informações }\end{array}$} & Subcategoria & Recorrência no discurso \\
\hline \multirow{2}{*}{$\begin{array}{l}\text { 2. Fornecimento de } \\
\text { informações }\end{array}$} & 1B. Clarificação & 1 \\
\cline { 2 - 3 } & 2A. Explicação & 4 \\
\cline { 2 - 3 } & 2B. Exposição simples & 10 \\
\hline 3. Problematização & 2C. Remodelamento & 0 \\
\hline 4. Reestruturação & - & 1 \\
\hline 5. Recondução & - & 0 \\
\hline 6. Reespelhamento & - & 6 \\
\hline 7. Acolhimento & - & 5 \\
\hline 8. Refutação & - & 0 \\
\hline
\end{tabular}

Por fim, ao olharmos para a sequência argumentativa de cada SR, identificamos que os processos argumentativos nos excertos retirados das SRs foram impulsionados por problematizações, a maioria delas partindo das mediadoras participantes do grupo Necce. Essas problematizações foram acolhidas (na SR \#2), refutadas (na SR \#4) e expandidas (na SR \#13). Nesse sentido, o projeto vai sendo configurado pelo grupo ao longo das sessões. 
Ainda, ao finalizarmos a nossa análise, precisamos refletir sobre o conceito de interdisciplinaridade que decorre do processo reflexivo-argumentativo das professoras da Cell ao final do projeto. Com base nas discussões desenvolvidas nas sessões reflexivas ao longo do processo de formação continuada na Cell, acreditamos que as professoras vão além da representação de interdisciplinaridade como integração de duas ou mais disciplinas (FAZENDA, 2009). A análise também destaca que trabalhar interdisciplinarmente significa trabalhar colaborativamente, tendo um objetivo comum orientando a prática escolar (GODOY, 2006, p. 36).

\section{Considerações finais}

Leitão (2007a, p. 82) argumenta que a investigação da evolução do processo argumentativo em ambientes instrucionais pode "oferecer à pesquisa do desenvolvimento humano um lócus privilegiado para o estudo de processos de formação e transformação do conhecimento". Nesse sentido, pudemos evidenciar que durante a construção do projeto pedagógico interdisciplinar as professoras da Cell engajaram-se na produção de conhecimento compartilhado a fim de ir ao encontro das necessidades de seu próprio contexto escolar. Da mesma forma, ao buscar a produção de atividades pedagógicas colaborativas e de caráter interdisciplinar, as professoras promoveram espaços de desenvolvimento do pensamento reflexivo, o qual foi mediado na/pela argumentação.

Em relação à recorrência das ações discursivas, percebemos que as categorias mais salientes são o reespelhamento, a exposição simples e o acolhimento. Podemos justificar a recorrência da categoria de reespelhamento ao longo das sessões, pois é por meio do reespelhar que comunicamos aos outros o nosso esforço de compreender o que foi posto e também, encorajamos o prosseguimento do discurso (COMPIANI, 1996, p. 45). 
Acreditamos ainda que a repetição da exposição simples se deve ao fato de estarmos construindo, colaborativamente, o projeto interdisciplinar, e, para isto, novas informações e ideias foram fornecidas incentivadas por problematizações ou por solicitações. Dessa maneira, as novas informações foram necessárias para dar desenvolvimento ao projeto (COMPIANI, 1996, p. 45). Já o acolhimento foi importante para a construção do processo argumentativo e reflexivo na Cell, pois incentivou e sustentou a prática interdisciplinar das professoras durante o projeto.

O processo argumentativo desenvolvido durante as sessões reflexivas desencadeado por problematizações que eram seguidas, via de regra, por acolhimento, exposições simples e reespelhamento -, além de moldar a construção do projeto interdisciplinar, auxiliando ainda na organização de ideias, na formação e na mudança de posições por parte das professoras. Tais aspectos nos sinalizam que, na argumentação, "rever as próprias posições a respeito de aspectos do mundo não é algo deixado para o indivíduo decidir se realiza ou não, mas, sim, uma consequência inevitável - de seu engajamento na própria atividade argumentativa" (LEITÃO, 2007a, p. 88).

\section{Referências}

BRUM, M. H. Representações de interdisciplinaridade por professores da rede pública ao longo de uma formação continuada. 2015. Dissertação (Mestrado em Estudos Linguísticos) - Universidade Federal de Santa Maria, Santa Maria, 150 p., 2015. DOI https://doi.org/10.26512/2015.05.d.19166

CELANI, M. A. A. Um programa de formação contínua. In: CELANI, M. A. A. (org.) Professores e formadores em mudança: relato de um processo de reflexão e transformação da prática docente. Campinas: Mercado de Letras, p. 19-35, 2002. DOI https://doi.org/10.1590/s0102-44502003000100011

COMPIANI, M. As geociências no ensino fundamental: um estudo de caso sobre o tema "A formação do universo", 1996. Tese (Doutorado em Educação) - Universidade Estadual de Campinas, SP, 215 p., 1996. DOI https://doi.org/10.17648/cied-2018-91665 
CRISTÓVÃO, V. L. L. Por relações colaborativas entre universidades e escolas. In: CRISTÓVÃO, V.; GIMENEZ, T. (org.). ENFOLI: Construindo uma comunidade de formadores de professores de inglês. Londrina: s.n., p. 19-22, 2005.

DAMIANOVIC, M. C. A organização argumentativa na passagem de formando a formador. In: LEITÃO, S.; DAMIANOVIC, M. C. (org.). Argumentação na escola: o conhecimento em construção. Campinas: Pontes Editores, p. 275-298, 2011.

DAMIANOVIC, M. C.; LEITÃO, S. A Atividade expansão de conceitos teóricos por meio do debate crítico em sala de aula. In: LIBERALI, F.; MATEUS, E.; DAMIANOVIC, M. C. (org.). A Teoria da Atividade Sócio-Histórico Cultural e a Escola: Recriando Realidades Sociais. Campinas. Editora Pontes, p. 137-160, 2012. DOI https://doi.org/10.11606/t.81.2018.tde-25072018-135159

DE CHIARO, S.; LEITÃO, S. O Papel do professor na construção discursiva da argumentação em sala de aula. Psicologia: Reflexão e Crítica, v. 18, n. 3, p. 340-358, 2005. DOI https://doi.org/10.1590/s0102-79722005000300009

FAZENDA, I. C. A. Didática e Interdisciplinaridade. 9. ed. Campinas, SP: Papirus, 2005.

FAZENDA, I. C. A. Formação de Professores: dimensão interdisciplinar. Revista Brasileira de Formação de Professores. Goiânia: v. 1, n. 1, p. 103-109, 2009. DOI https://doi.org/10.31639/rbpfp.v11i20.210

FREIRE, P. Cartas a Cristina: reflexões sobre minha vida e minha práxis. 2.ed. São Paulo: UNESP, 2003.

GODOY, A. C. S. A interdisciplinaridade na formação docente. Revista de Educação, v. 9.2006 .2 Disponível em: http://sare.anhanguera.com/index.php/reduc/article/viewArticle/194. Acesso em: 15 abr. 2016.

LEFFA, V. J. Transdisciplinaridade no ensino de línguas: a perspectiva das teorias da complexidade. Revista Brasileira de Linguística Aplicada, Belo Horizonte, v. 6, n. 1, 2006. DOI https://doi.org/10.1590/s1984-63982006000100003

LEITÃO, S. Contribuições dos estudos contemporâneos da argumentação à uma análise psicológica de processos de construção de conhecimento em sala de aula. Arquivos Brasileiros de Psicologia, Rio de Janeiro, v. 51, n. 1, p. 91-109, 1999. DOI https://doi.org/10.11606/d.81.2011.tde-25072011-135057 
LEITÃO, S. The potential of argument in knowledge building. HumanDevelopment, v. 6, p. 332-360, 2000.

LEITÃO, S. Processos de construção do conhecimento: a argumentação em foco. Proposições, v. 18, n. 3, p. 75-90, 2007a.

LEITÃO, S. Argumentação e Desenvolvimento do Pensamento Reflexivo. Psicologia: Reflexão e Crítica, v. 20, n. 3, p. 454-462, 2007b. DOI https://doi.org/10.1590/s010279722007000300013

LEITÃO, S. O Lugar da Argumentação na Construção do Conhecimento em Sala de Aula. In: LEITÃO, S.; DAMIANOVIC, M. C. (org.). Argumentação na Escola: O Conhecimento em Construção. Campinas: Pontes, p. 13-46, 2011. DOI https://doi.org/10.1590/s0102-79722005000300009

LENOIR, Y. Didática e interdisciplinaridade: uma complementaridade necessária e incontornável. In: FAZENDA, I. C. (org.). Didática e interdisciplinaridade. 13. ed. Campinas: Papirus, 2008.

LIBERALI, F. Formação crítica de educadores: questões fundamentais. Coleção novas perspectivas em linguística aplicada. 2. ed. v. 8. Campinas: Pontes Editores, 2012.

MAGALHÃES, M. C. C. O professor de línguas como pesquisador de sua ação: a pesquisa colaborativa. In: GIMENEZ, T. (org.). Trajetórias na formação de professores de línguas. Londrina: UEL, 2002. p. 39-58. DOI https://doi.org/10.5935/19814755.20170005

MAGALHÃES, M. C. Questões de método e de linguagem na formação docente. Campinas, SP: Mercado de Letras, 2011.

MOTTA-ROTH, D. Competências comunicativas interculturais no ensino de inglês como língua estrangeira. In: MOTTA-ROTH, D.; BARROS, N. C.; RICHTER, M. G. (org.). Linguagem, cultura e sociedade. Santa Maria, RS: PPGL Editores/UFSM, 2006. p. 191-201.

MOTTA-ROTH, D. Para ligar a teoria à prática: roteiro de perguntas para orientar a leitura/análise crítica de gênero. In: MOTTA-ROTH, D.; CABAÑAS, T.; HENDGES, G. R. (org.). Análises de textos e de discursos: relações entre teorias e práticas. 2 ed. Santa Maria: PPGL, 2008. p. 243-272. DOI https://doi.org/10.1590/s0102-44502008000200007 
PONTECORVO, C.; GIRARDET, H. Arguing and Reasoning in Understanding Historical Topics. Cognition and Instruction, v. 11, n. 3-4, 1993. p. 365-39. DOI https://doi.org/10.1080/07370008.1993.9649030

SILVA, E. A. Representações de Letramento no Contexto Escolar: A construção de um conceito socialmente situado em um programa de formação de professores. 2014. Dissertação (Mestrado em Estudos Linguísticos) - Universidade Federal de Santa Maria, Santa Maria, 141 p., 2014. DOI https://doi.org/10.4013/cld.2017.151.05

VAN EEMEREN, F. H.; GROOTENDORST, R. A Systematic Theory of Argumentation. Cambridge: University Press, 2009. 